\title{
Effects of Chemical Composition on the Corrosion of Dental Alloys
}

\author{
Rodrigo GALO ${ }^{1}$ \\ Ricardo Faria RIBEIRO ${ }^{1}$ \\ Renata Cristina Silveira RODRIGUES ${ }^{1}$ \\ Luís Augusto ROCHA ${ }^{2}$ \\ Maria da Glória Chiarello de MATTOS $^{1}$ \\ ${ }^{1}$ Department of Dental Materials and Prosthodontics, Ribeirão Preto Dental School, \\ USP - University of São Paulo, Ribeirão Preto, SP, Brazil \\ ${ }^{2}$ Centre for Mechanics and Materials Technologies, Department of Mechanical Engineer, Minho University, Portugal
}

\begin{abstract}
The aim of this study was to determine the effect of the oral environment on the corrosion of dental alloys with different compositions, using electrochemical methods. The corrosion rates were obtained from the current-potential curves and electrochemical impedance spectroscopy (EIS). The effect of artificial saliva on the corrosion of dental alloys was dependent on alloy composition. Dissolution of the ions occurred in all tested dental alloys and the results were strongly dependent on the general alloy composition. Regarding the alloys containing nickel, the Ni-Cr and Ni-Cr-Ti alloys released $0.62 \mathrm{mg} / \mathrm{L}$ of $\mathrm{Ni}$ on average, while the Co-Cr dental alloy released ions between 0.01 and $0.03 \mathrm{mg} / \mathrm{L}$ of $\mathrm{Co}$ and $\mathrm{Cr}$, respectively. The open-circuit potential stabilized at a higher level with lower deviation (standard deviation: $\mathrm{Ni}-\mathrm{Cr}-6 \mathrm{Ti}=32 \mathrm{mV} / \mathrm{SCE}$ and $\mathrm{Co}-\mathrm{Cr}=54 \mathrm{mV} / \mathrm{SCE}$ ). The potenciodynamic curves of the dental alloys showed that the Ni-based dental alloy with $>70 \mathrm{wt} \%$ of $\mathrm{Ni}$ had a similar curve and the Co-Cr dental alloy showed a low current density and hence a high resistance to corrosion compared with the Ni-based dental alloys. Some changes in microstructure were observed and this fact influenced the corrosion behavior for the alloys. The lower corrosion resistance also led to greater release of nickel ions to the medium. The quantity of Co ions released from the Co-Cr-Mo alloy was relatively small in the solutions. In addition, the quantity of $\mathrm{Cr}$ ions released into the artificial saliva from the $\mathrm{Co}-\mathrm{Cr}$ alloy was lower than $\mathrm{Cr}$ release from the Ni-based dental alloys.
\end{abstract}

Key Words: Corrosion, metal ions, metal (alloys), surface characterization.

\section{INTRODUCTION}

Corrosion can be described as the deterioration of materials by aggressive action of the atmosphere and/or oral fluids. This term is used for metallic materials, and the mechanism of corrosion is mainly electrochemical when considering those environments (1). Dental alloys are generally placed in the mouth of patients for many years where they have to resist simultaneously to mechanical loads and to environmental corrosion.

The degradation of a material is said to be continuous in the mouth due to abrasion of foods, liquids and toothbrushes (2) originating metallic ions and/or debris. These ions and/or debris released from dental alloys can induce adverse biological reactions such as gingival swelling and erythema, mucosal pain or lichenoid reactions. If these ions are not tolerated by the organism, then the organism may be injured (toxicity and risk of sensitization) and if they are absorbed in sufficient quantity, clinical implant failure can happen due to osteolysis, cutaneous allergic reactions, or remote site accumulation (3).

Nickel and other metal, such as chromium and cobalt, are commonly used for the fabrication of prosthesis and substructure of metal-ceramic crowns, where fine frameworks constructions are needed (4). These substructures were introduced into dentistry as a possible replacement for precious alloys due to the increasing cost of gold throughout the 1980's (5). Dental alloys offer the advantage of allowing thinner section of

Correspondence: Profa. Dra. Maria da Glória Chiarello de Mattos, Departamento de Materiais Dentários e Prótese, Faculdade de Odontologia de Ribeirão Preto, Universidade de São Paulo, Avenida do Café S/N, Monte Alegre, 14040-904 Ribeirão Preto, SP, Brasil. Tel: +55-16-3602-4098. Fax: +55-016-3602-4780. e-mail:gloria@forp.usp.br 
the alloy to be used, and consequently less tooth sound destruction during the crown preparation.

However, dental alloys react easily with the biochemical medium in the oral cavity, and doubts remain about their biocompatibility when used in restorative procedures. Sometimes, the prostheses are placed in close proximity to the gingival and often extend sub-gingivally, where corrosion processes may cause higher adverse reactions (2). So, the selection is made depending on the clinical indication and, in case of an inadequate material selection, problems may lead to mechanical, chemical or biological failures that have undesirable consequences over time for the patient's general health (6).

Small variations of the chemical composition of dental alloys may affect the corrosion performance. From this point of view, Be-free Ni-Cr alloys are preferred for dental use (7) and extensive research has been carried out on corrosion resistance of $\mathrm{Ni}$-Cr-based alloys relative to bonding composite (7). Gil et al. (8) found that the Ni-Cr-based alloy exhibits significant corrosion and that a high quantity of ions is released, and that, due to the allergic effect of $\mathrm{Ni}$ and $\mathrm{Cr}$ ions, the use of $\mathrm{Ni}$-Cr-based alloys should be considered carefully.

The increase in allergies and the need for prolonged use require prostheses having less metal release (1). Therefore, in addition to considering usage conditions and duration, the behavior of metal release from each metallic biomaterial should be examined for proper selection of dental alloys, using various materials simulated human saliva fluids. However, there are insufficient research studies that adequately compare metal release from dental prosthesis materials using saliva under the same experimental conditions.

The aim of the this study was to evaluate the effect of the oral environment on the corrosion of dental alloys with different compositions, using electrochemical methods.

\section{MATERIAL AND METHODS}

\section{Materials and Sample} Preparation

Four commercial dental alloys were evaluated, namely Ni-Cr (Vera Bond II; AALBA Dent. Inc., Fairfield, CA, USA), Ni-Cr-6Ti (ViStar; Talladium
Inc., Valencia, CA, USA), Co-Cr (Remanium; Dentaurum, Pforzheim, German) and Ni-Cr-4Ti (Tilite Ômega; Talladium Inc.). The chemical composition (mass \%) of the alloys determined by the manufactures is given in Table 1.

Metallic plate specimens ( $40 \times 20 \times 3 \mathrm{~mm})$ were produced by the lost-wax technique in a casting machine (Discovery Plasma; EDG, São Carlos, SP, Brazil) using an electric arc melting in vacuum, under an argon atmosphere, with injection of the metal into the mould (phosphated investment Rema Exakt; Dentaurum) by vacuum pressure plasma, according to the manufacture's recommendation. Specimens were wet-ground to 2400 grade silicon carbide grinding paper (Metprep, Conventry, UK) followed by two polishing stages ( 3 and $1 \mu \mathrm{m}$ ) with diamond suspension (Struers, Glasgow, UK). Before testing, specimens were ultrasonically cleaned in ethanol during $10 \mathrm{~min}$ and in distilled water during $10 \mathrm{~min}$. The samples were well dried with hot air and kept in the desiccator until the beginning of the test.

The surface roughness was measured with a profilometer (Perthometer S5P; Feinpruf Perthen, Gottingen, Germany), which contacted the surface at a constant speed of $0.05 \mathrm{~mm} / \mathrm{s}$ with a force of 0.7 $\mathrm{mN}$. Surface roughness was characterized by the $R_{a}$ parameter, which is the arithmetical mean of the absolute values of the profile departures within the evaluated length. Statistical calculation of surface roughness independently of polishing was performed using an average of 12 surface roughness measurements parallel to the long axis at the central segment of each specimen.

\section{Electrochemical Measurements}

The electrochemical measurements were performed using a potentiostast (PGP201; Radiometer Analytical, Copenhagen, Denmark) controlled by the Voltamaster-4 software running under a computer (Voltamaster; Radiometer Analytical). The edge of the sample area was defined by pressing sample against an
Table 1. Chemical composition of the dental alloys (wt \%).

\begin{tabular}{lcccccccccc}
\hline Alloy & $\mathrm{Cr}$ & $\mathrm{Ni}$ & $\mathrm{Co}$ & $\mathrm{Ti}$ & $\mathrm{W}$ & $\mathrm{Mo}$ & $\mathrm{Nb}$ & $\mathrm{Si}$ & $\mathrm{Al}$ & Other \\
\hline Co-Cr & 25.00 & & 61.00 & & 5.00 & 7.00 & & 1.50 & & \\
Ni-Cr-6Ti & 12.00 & 72.00 & & 6.00 & & 4.50 & & & & Bal. \\
Ni-Cr-4Ti & 20.00 & 66.00 & & 4.00 & & 10.00 & & & & \\
Ni-Cr & 11.50 & 75.55 & & & & 3.50 & 4.25 & 3.50 & 2.25 & \\
\hline
\end{tabular}


O-ring exposing an area of $3.64 \mathrm{~cm}^{2}$. Potentials were measured against a standard calomel electrode - SCE (B20B110; Radiometer Analytical) and a platinum plate served as the counter electrode, with an exposure area of $1 \mathrm{~cm}^{2}$ (wire B35M110; Radiometer Analytical).

Modified Fusayama's artificial solution (AS) was used as an electrolyte, consisting of $\mathrm{NaCl}(400 \mathrm{mg} / \mathrm{L})$, $\mathrm{KCl}(400 \mathrm{mg} / \mathrm{L}), \mathrm{CaCl}_{2} \cdot \mathrm{H}_{2} \mathrm{O}(795 \mathrm{mg} / \mathrm{L}), \mathrm{NaH}_{2} \mathrm{PO}_{4} \cdot \mathrm{H}_{2} \mathrm{O}$ $(690 \mathrm{mg} / \mathrm{L}), \mathrm{NaS} 9 \mathrm{H}_{2} \mathrm{O}(5 \mathrm{mg} / \mathrm{L})$, and urea $(1000 \mathrm{mg} / \mathrm{L})$ (Sigma Chemical Company, St. Louis, MO, USA). This solution was prepared daily by adding these chemicals to distilled water and presented a final $\mathrm{pH}$ of approximately 5.3. Tests were performed at $37 \pm 1^{\circ} \mathrm{C}$ by immersing the electrochemical cell in a heated water-bath.

The corrosion potential $\left(\mathrm{E}_{\text {corr }}\right)$ was followed during $1 \mathrm{~h}$ after immersion. Therefore, the potentiodynamic polarization curves were carried out from $-400 \mathrm{mV}$ to $+1000 \mathrm{mV}$ vs. SCE, at a scanning rate of $2 \mathrm{mV} / \mathrm{s}$. The test was repeated three times with each alloy.

Electrochemical impedance spectroscopy (EIS) measurements were also made using a GalvanostatPotentiostat PGZ 100 (Radiometer Analytical), controlled by Voltamaster-4 software described before. The EIS measurements were made at the corrosion potential in the conditions described above. The frequencies for EIS measurement were chosen in the range from $100 \mathrm{kHz}$ to $5 \mathrm{mHz}$ with an applied sinusoidal potential of $10 \mathrm{mV}$.

An equivalent circuit was modeled and fitted to the EIS experimental data by using the Zview software $\left(\right.$ ZPlot $^{\circledR}$ and ZView ${ }^{\circledR}$ for Windows Software; Scribner Associates Inc., Southern Pines, NC, USA).

\section{Ion Concentration}

Following the polarization test, $50 \mathrm{~mL}$ of of AS was subjected to chemical analysis using an atomic absorption spectrometer (GBC model 904AA, Scientific Equipment Pty, Victoria, Australia) . Specific lamps for the detection of $\mathrm{Ni}, \mathrm{Cr}, \mathrm{Co}$, and $\mathrm{Ti}$ ions were used in the analysis.

\section{Analyses of Surface}

The surfaces of specimens were examined using a scanning electron microscope (Philips XL-30 ESEMFEG; Eindhoven, The Netherlands) and the elemental distribution was studied using an energy-dispersive x-ray spectroscopy (EDS; Philips XL-30 ESEM-FEG).

\section{Statistical Analysis}

Data were analyzed statistically by oneway ANOVA to assess the influence of material in AS followed by Duncan test $(\alpha=0.05)$ for multiple comparisons. Statistical analysis was done using SPSS software version 12.0 (SPSS Inc., Chicago, IL, USA).

\section{RESULTS}

The evolution of the potentials recorded under open-circuit conditions for the various alloys versus time are shown in Figure 1 and all mean values and standard deviations of alloys are given in Table 2. As a general tendency, the potential slightly increased as soon as the samples were immersed in the Fusayama's solution and then stabilized after $30 \mathrm{~min}$, except for the Ni-Cr-4Ti that the potential decreased versus time.

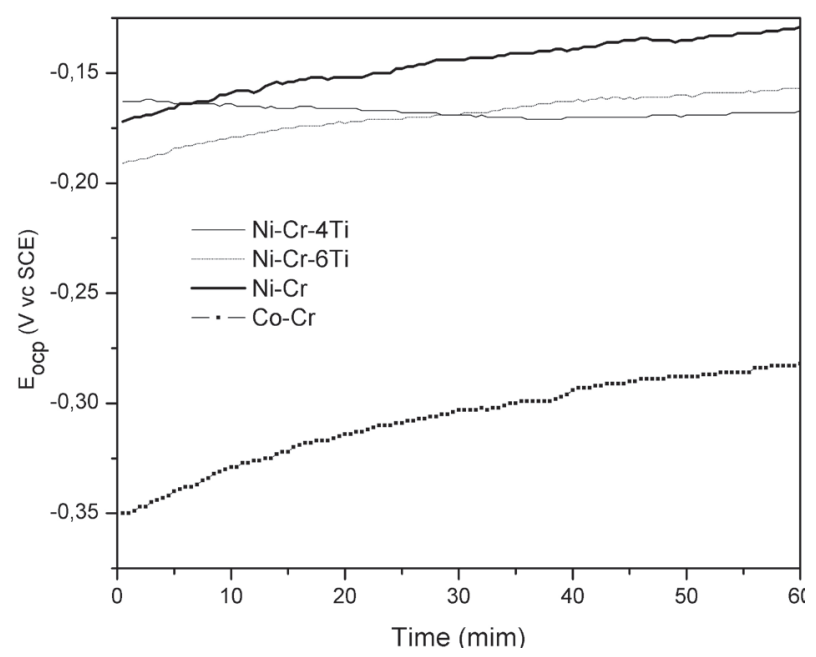

Figure 1. Evolution of the corrosion potential $\left(\mathrm{E}_{\text {corr }}\right)$ of the dental alloys over time.

Table 2. Summary of the electrochemical parameters evaluated from the potentiodynamic polarization measurements (artificial saliva, $\left.37^{\circ} \mathrm{C}\right)$.

\begin{tabular}{lcc}
\hline Alloy & $\mathrm{E}_{\text {ocp }}(\mathrm{mV})$ & $\mathrm{i}_{\text {corr }}\left(\mu \mathrm{A} / \mathrm{cm}^{2}\right)$ \\
\hline Ni-Cr-6Ti & $-138.34 \pm 18.666$ & $0.041 \pm 0.018$ \\
Co-Cr & $-300 \pm 15.275$ & $0.0203 \pm 0.005$ \\
Ni-Cr-4Ti & $-189 \pm 31.606$ & $0.023 \pm 0.011$ \\
Ni-Cr & $-132.67 \pm 14.746$ & $0.036 \pm 0.005$ \\
\hline
\end{tabular}


The dental alloy Ni-Cr with the highest content in $\mathrm{Ni}$ (>70 $\mathrm{wt} \%$ ) had noble behavior (-130 to $-190 \mathrm{mV} / \mathrm{SCE}$ ). The Ni-Cr-4Ti alloy with less Ni (60-70 wt\%) had an open-circuit potential below -190 mV/SCE. The Co-Cr dental alloy showed the lowest open-circuit potential of $-300 \mathrm{mV} / \mathrm{SCE}$.

For the Ni-Cr-6Ti and Co-Cr alloys (Fig. 1), the values obtained for the open-circuit potential after $30 \mathrm{~min}$ of immersion were very scattered and had a high standard deviation. After increasing the time of immersion up to $1 \mathrm{~h}$, the open-circuit potential stabilized at a higher level with lower deviation (standard deviation: $\mathrm{Ni}-\mathrm{Cr}-6 \mathrm{Ti}=$ $32 \mathrm{mV} / \mathrm{SCE}$ and $\mathrm{Co}-\mathrm{Cr}=54 \mathrm{mV} / \mathrm{SCE}$ ). After $1 \mathrm{~h}$, these open-circuit potential steady over time.

The potenciodynamic curves of dental alloys are presented in Figure 2. The current density is correlated with the corrosion rate. A high current density (current on the surface) at the corresponding potential indicated a high corrosion rate of the alloy. Comparison between the dental alloy curves shows that the Ni-based dental alloy with $>70 \mathrm{wt} \%$ of Ni had a similar curve. The $\mathrm{Co}-\mathrm{Cr}$ dental alloy showed a low current density and therefore a high resistance to corrosion compared with the Ni-based dental alloys.

Before the potentiodynamic polarization tests, no attack was identified on any specimen and all specimens showed heterogeneous microstructure. After the test, dissolution in the dental alloys and pits were seen on most specimens, except for the Co-Cr specimens (Fig. 3).

The EIS spectra, more specifically the Nyquist plots obtained at the open-circuit potential for the alloys in the saliva solution, during 1, 24 and $48 \mathrm{~h}$ are presented in Figure 4 . The corresponding $R_{p}$ values are listed in Table 3.

As shown in Figure 4, all specimens were approximately characterized by one large semicircle. The diameter of the semicircle for $\mathrm{Co}-\mathrm{Cr}$ specimens was larger than that of the other specimens. As listed in Table 3, the $R_{p}$ in the 1-h period was significantly different for Ni-Cr-4Ti ( $\mathrm{p} \leq 0.05)$; it was less than 0.13 $\mathrm{M} \Omega-\mathrm{cm}^{2}$. In the 1-day experiment, the same situation was observed, where the Ni-Cr-4Ti was significantly different $(p \leq 0.05)$ from the other alloys. In day 2 , the $R_{p}$ increased for all the alloys, except for $\mathrm{Co}-\mathrm{Cr}$, but it was
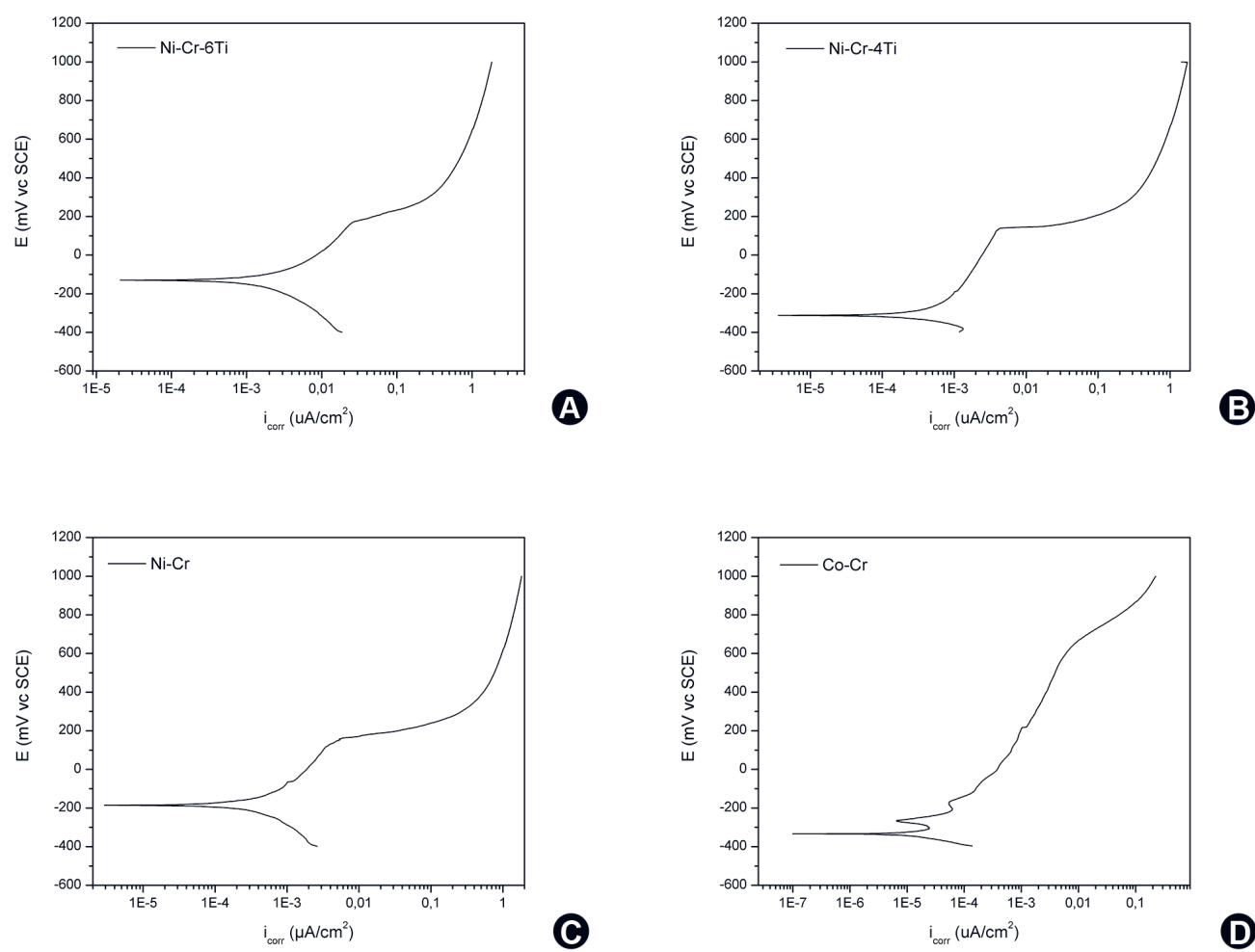

C

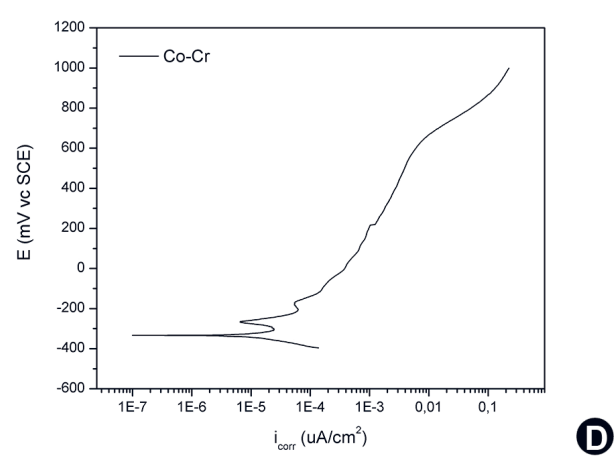

Figure 2. Potentiodynamic polarization curves obtained for dental alloys immersed in artificial saliva solution. A; Ni-Cr-6Ti; B: NiCr-4Ti; C: Ni-Cr; and D: Co-Cr. 

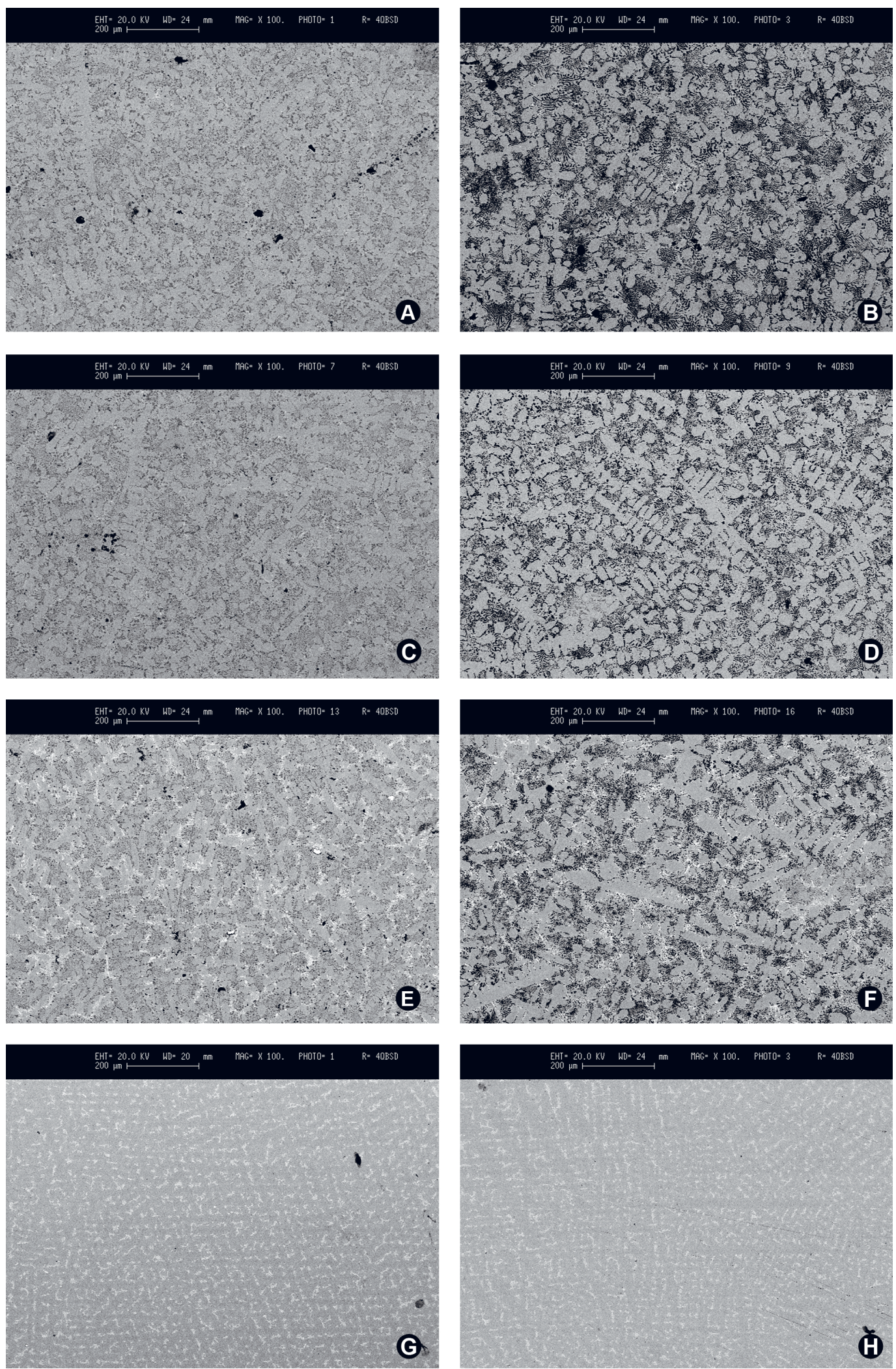

Figure 3. Composite figure of SEM micrographs of the dental alloys before (left column) and after (right column) the polarization tests in artificial saliva solution (potentiodynamic polarization). A and B: Ni-Cr alloy; C and D: Ni-Cr-6Ti alloy; E and F: Ni-Cr-4Ti alloy; G and H: Co-Cr alloy. 
not statistically different from the other days. Based on visual observation and impedance spectra, the corrosion behavior was modeled by an equivalent circuit (Fig. 5).

After immersion in the saliva solution, the alloys released some metallic ions (Table 4). The $\mathrm{Ni}-\mathrm{Cr}$ and $\mathrm{Ni}-\mathrm{Cr}-\mathrm{Ti}$ alloys released $0.62 \mathrm{mg} / \mathrm{L}$ of Ni-ions and 0.07 $\mathrm{mg} / \mathrm{L}$ of Cr-ions on average. The Ti concentration in AS was below the detection limit $(0.05 \mathrm{mgL} / \mathrm{L})$. The $\mathrm{Co}-\mathrm{Cr}$ alloy released between 0.01 and $0.03 \mathrm{mg} / \mathrm{L}$ of $\mathrm{Co}$ and $\mathrm{Cr}$ ions, respectively.

\section{DISCUSSION}

The importance of the corrosion tests in dentistry has increased because the oral galvanic actions may cause a series of reactions starting from a metal taste, oral burning, oral pain, sensitizations, allergies and other toxic reactions (9). Dental alloys require both biomedical safety and biomechanical compatibility. In terms of biomechanical compatibility, it is necessary that the mechanical properties and corrosion resistance do not degrade over prolonged use. In particular, high corrosion resistance, resulting in low or negligible ion

Table 3. $\mathrm{R}_{\mathrm{p}}\left(\mathrm{M} \Omega / \mathrm{cm}^{2}\right)$ values obtained from EIS measurements (means \pm standard deviation).

\begin{tabular}{lccc}
\hline \multirow{2}{*}{ Alloy } & \multicolumn{3}{c}{ Experimental period } \\
\cline { 2 - 4 } & $1 \mathrm{~h}$ & $24 \mathrm{~h}$ & $48 \mathrm{~h}$ \\
\hline $\mathrm{Ni}-\mathrm{Cr}$ & $0.297 \pm 0.054$ & $0.307 \pm 0.012^{+*}$ & $0.554 \pm 0.013$ \\
$\mathrm{Ni}-\mathrm{Cr}-$ & $0.285 \pm 0.027$ & $0.280 \pm 0.018^{+*}$ & $0.348 \pm 0.023$ \\
$6 \mathrm{Ti}$ & $0.391 \pm 0.064^{*}$ & $0.413 \pm 0.007^{*}$ & $0.663 \pm 0.234$ \\
$\mathrm{Co}-\mathrm{Cr}$ & & $0.222 \pm 0.021$ & $0.266 \pm 0.003$ \\
$\begin{array}{l}\mathrm{Ni}-\mathrm{Cr}- \\
\text { 4Ti }\end{array}$ & $0.130 \pm 0.001$ & & \\
\hline
\end{tabular}

${ }^{*,+}$ statistically different $(\mathrm{p} \leq 0.05)$. release, is a requirement for dental alloys.

Generally a high open-circuit potential value indicates a high tendency to resist to corrosion. Ni-based dental alloys have high open-circuit potential, thus they all have a high tendency to resist to corrosion. However, when the material has a low open-circuit potential such as dental alloys with $\mathrm{Ti}$ and $\mathrm{Cr}$, there are two possible reasons: 1 . either the metal has the tendency to oxidize or form soluble compounds (then it is very corrodible), 2. or the metal forms insoluble products, mostly oxide layers on the surface, which minimizes the corrosion and results in highly resistant material (e.g.: Ti) (10). Ni-based dental alloys had negative open-circuit potential values but not very low $(\approx-180 \mathrm{mV} / \mathrm{SCE})$. Some alloys with high Ni content ( $>70 \mathrm{wt} \%$ ) showed higher open-circuit potential values than $\mathrm{Co}-\mathrm{Cr}$, for example $\mathrm{Ni}-\mathrm{Cr}$ (Fig. 1).

Reclaru et al. (11) demonstrated that some Co-Cr dental alloys do not have a higher corrosion resistance. However, this is not consistent with the observations of Sun et al. (12), who found that Co-Cr alloy presented better corrosion behavior than Ni-based dental alloys, due to $\mathrm{Cr}$ and Mo contents (13).

For determination of corrosion resistance, it is not sufficient only to consider the open-circuit potential to resistance to corrosion of dental alloys, especially due to the short immersion time of $2 \mathrm{~h}$, according to ISO 10271 standard. The polarization curves were found to be very appropriate to study the entire resistance to corrosion.

The current densities of corrosion measured were low for the $\mathrm{Co}-\mathrm{Cr}$ dental alloy $\left(0.02 \mu \mathrm{A} / \mathrm{cm}^{2}\right)$. However, the Ni-based dental alloys show more susceptible to corrosion. The Ni-based alloys showed a corrosion process that was related to the corrosive media. These results showed that dental alloys with $\mathrm{Ni}$ and $\mathrm{Cr}$ are the most corrosive element in AS.

Generally, corrosion resistance is due
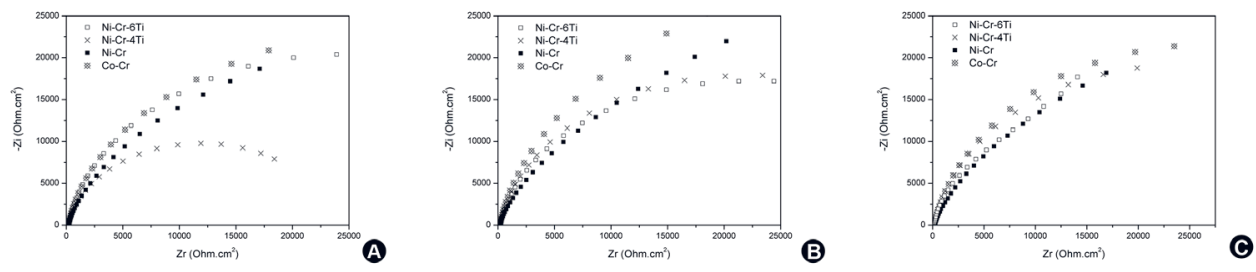

Figure 4. The Nyquist plots of the dental alloys in artificial saliva after different periods: A: $1 \mathrm{~h}$; B: $24 \mathrm{~h}$; and C: $48 \mathrm{~h}$. 
to the formation of a protective passive layer (oxide). The stronger the passive layer, the better the corrosion resistance of a dental alloy. The quantity of released metal changes markedly depending on the nature and strength of the metal-oxide bond, structure (vacancies, interstitial elements, degree of ordering), role of alloying element, composition and thickness of oxide layers (1). The role of alloying element in a passive layer formed on the presence of $\mathrm{Cr}$ and Mo in Ni-based dental casting alloys makes them more corrosion resistant by the formation of a surface oxide layer $(14,15)$. It has been reported that only Ni-based dental alloys containing 16\% to $27 \% \mathrm{Cr}$ develop an adequate protective oxide layer (15). Although among the tested Ni-based dental alloys only Ni-Cr-4Ti alloy had an adequate $\mathrm{Cr}$ content, no differences in corrosion behavior were detected. On the other hand, Mo also has an active role in the formation of this protective oxide layer. Thus, an increasing concentration of $\mathrm{Cr}$ and Mo on the surface layer may synergistically lower metal dissolution rates (14), which may subsequently reduce the cytotoxicity of the alloys.

The SEM analysis (Fig. 3) showed that the corrosion process initially occurs on the surface. Pits may be the result of the dissolution of the precipitates of the AS or, respectively, their detachment due to the dissolution. The Co-Cr surface itself did not show any evidence of significant corrosion. The Ni-based dental alloys presented a more severely corroded surface, with the formation of a typical surface morphology of a uniform corrosion with the dissolution of the corrosion products. Visually, the surface was blackened. In the Ni-based dental alloys, corrosion was observed in the area around of Ti element, but it did not remove the Ti nor this element stopped the corrosion process.

The impedance of surface layer on metal can be larger than of change transfer reaction of metal, leading to the disappearance of the impedance of metal's charge transfer reaction in the Nyquist plot (13). In other words,

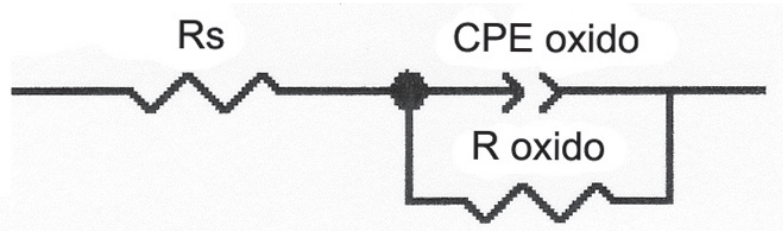

Figure. 5 Circuit equivalent of the interface of corrosive, test electrolyte and alloy exposed by a saliva artificial solution (Rs - electrolyte resistance; R oxide - oxide resistance; CPE oxide double layer capacity). when a protection surface film is formed on metal, the metal impedance corresponds to the impedance of surface passive layer because the impedance of metal's charge transfer reaction is relatively small and can thus be neglected. In this study, the semicircle observed in the Nyquist plot for each specimen (Fig. 4) was mainly described to the presence of the surface passive layer. Therefore, the $\mathrm{R}_{\mathrm{p}}$ values obtained from the Nyquist plot mainly represented the corrosion resistance of passive layer, and the model made it possible to obtain an order of magnitude for the polarization resistance values.

As shown in Table 3, the $\mathrm{R}_{\mathrm{p}}$ values for all specimens were higher than $0.1 \mathrm{M} \Omega / \mathrm{cm}^{2}$, being the Co$\mathrm{Cr}$ specimen the one that presents the highest value $(\approx 0.6$ $\mathrm{M} \Omega / \mathrm{cm}^{2}$ ). Huang (16) found that $\mathrm{R}_{\mathrm{p}}$ of Ni-based dental alloy in AS is around $1 \mathrm{M} \Omega / \mathrm{cm}^{2}$, with an acceptable corrosion resistance that related to the compositional difference in the passive layer. Therefore, the passive layers formed in the alloys used in this study exhibited a lower corrosion resistance in the AS. However, Co-Cr alloy has better corrosion resistance $\left(\mathrm{R}_{\mathrm{p}}\right)$ than Ni-based alloys, due to a stronger surface oxide layer (17).

However, after 2 days, the dental alloys did not show any difference in the $\mathrm{R}_{\mathrm{p}}$ values. The presence of $\mathrm{Cr}$ in the alloy can improve the corrosion resistance in this corrosion environment due to the formation of a $\mathrm{Cr}$-rich passive oxide layer, which had a higher resistance to acid attack. In other studies $(13,15)$, Ni-based dental alloys had stronger corrosion resistance, due to an important role which $\mathrm{Cr}$ and Mo plays in the corrosion resistance of this alloy.

The corrosion products analyzed by a graphitefurnace atomic absorption spectrometer showed that the $\mathrm{Ni}$ ion was the element found in the greatest quantity.

Table 4. Metal concentrations $(\mathrm{mg} / \mathrm{L})$ in artificial saliva, at $37^{\circ} \mathrm{C}$ after the Potentiodynamic polarization.

\begin{tabular}{lccc}
\hline \multirow{2}{*}{$\begin{array}{l}\text { Dental } \\
\text { alloy }\end{array}$} & $\mathrm{Ni}$ & $\mathrm{Cr}$ & $\mathrm{Co}$ \\
\cline { 2 - 4 } & $\mathrm{Ni}$ & - \\
\hline $\begin{array}{l}\mathrm{Ni}-\mathrm{Cr}- \\
6 \mathrm{Ti}\end{array}$ & $0.536 \pm 0.223$ & $0.05 \pm 8.5 \mathrm{E}^{-18}$ & - \\
$\mathrm{Ni}-\mathrm{Cr}-$ & $1.1537 \pm 0.024$ & $0.05 \pm 8.5 \mathrm{E}^{-18}$ & - \\
$4 \mathrm{Ti}$ & & & - \\
$\mathrm{Ni}-\mathrm{Cr}$ & $0.2067 \pm 0.046$ & $0.0665 \pm 0.0191$ & \\
& & & \\
$\mathrm{Co}-\mathrm{Cr}$ & - & $0.0379 \pm 0.0379$ & $0.0093 \pm 0.009$
\end{tabular}


In particular, the same areas are related directly with the element $\mathrm{Ni}$, which explains the blackened surface. The Ni-Cr-4Ti dental alloy was more susceptible to corrosion and is thus likely to release more metal ions to the oral environment, which can generate allergic problems $(8,14)$. However, adverse reactions to Ni were shown to be more common in extraoral than intraoral applications (18). Other authors (19) found that the lower level of Ni released compared with other studies (20) may be below the threshold required for triggering an allergic reaction, at least in subjects without history of sensitization to the metal.

This study demonstrated the importance of the content of different components in dental alloys. The presence of higher $\mathrm{Cr}(25 \mathrm{wt} . \%)$ in the bulk alloy led to higher corrosion resistance compared with a lower $\mathrm{Cr}$ (12 wt.\%) content. Some changes in microstructure were observed during the study and influenced the corrosion behavior of the tested alloys. The lower corrosion resistance also led to a greater release of $\mathrm{Ni}$ ions to the medium and the quantity of Co ions released from the CoCr-Mo dental alloy was relatively small in the solutions.

\section{RESUMO}

O objetivo deste estudo foi determinar o efeito do ambiente bucal na corrosão de diferentes ligas odontológicas, utilizando métodos eletroquímicos. Os índices de corrosão foram obtidos por meio das curvas de corrente-potencial e impedância eletroquímica (EIS). O efeito de saliva artificial na corrosão de ligas odontológicas foi dependente da composição. A dissolução dos íons ocorreu em todas as amostras e os resultados foram dependentes da composição da liga. Algumas mudanças na microestrutura foram observadas durante o estudo e influenciou o comportamento corrosivo das ligas investigadas. As ligas de $\mathrm{Ni}-\mathrm{Cr}$ e Ni-Cr-Ti libertaram quantidade de $0,62 \mathrm{mg} / \mathrm{L}$ de íons $\mathrm{Ni}$ enquanto a liga de $\mathrm{Co}-\mathrm{Cr}$ liberou entre 0,01 e $0,03 \mathrm{mg} / \mathrm{L}$. As curvas potenciodinâmicas das ligas odontológicas mostraram que as ligas a base $>70 \mathrm{wt} \%$ de Ni obtiveram curvas similares e a liga de $\mathrm{Co}-\mathrm{Cr}$ apresentou a menor densidade de corrente e em consequência uma resistência alta a corrosão quando comparada as ligas à base de Ni. A baixa resistência à corrosão também levou a maior libertação de íons de níquel para o meio e a quantidade de Co liberado pela liga de Co-Cr-Mo foi relativamente pequena nas soluções. As quantidades de $\mathrm{Cr}$ liberada na saliva artificial pela liga de $\mathrm{Co}-\mathrm{Cr}$ foi menor que a libertação de $\mathrm{Cr}$ pela liga à base de Ni.

\section{ACKNOWLEDGEMENTS}

The authors acknowledge CAPES for financial support. metallic biomaterials in vitro. Biomaterials 2005;26:11-21.

2. Schmalz G. Materials science: biological aspects. J Dent Res 2002;81:660-663.

3. Molina C, Nogués L, Martinez-Gomis J, Peraire M, Salsench J, Sevilla P, et al.. Dental casting alloys circuit during power toothbrushing with toothpastes of various abrasivities. Part II: corrosion and ion release. J Mater Sci Mater Med 2008;19:30153019.

4. Anusavice KJ. In: Phillips' science of dental materials. London: Saunders; 2003. pp. 594.

5. Leinfelder KF. An evaluation of casting alloys used for restorative procedures. J Am Dent Assoc 1997;128:37-45.

6. Mareci D, Nemtoi G, Aelenei N, Bocanu C. The electrochemical behavior of various non-precious $\mathrm{Ni}$ and Co based alloys in artificial saliva. Eur Cell Mater 2005;10:1-7, discussion 1-7.

7. Geis-Gerstorfer J, Pässler K. Studies on the influence of Be content on the corrosion behavior and mechanical properties of $\mathrm{Ni}-25 \mathrm{Cr}-$ 10Mo alloys. Dent Mater 1993;9:177-181.

8. Gil FJ, Sánchez LA, Espías A, Planell JÁ. In vitro corrosion behavior and metallic ion release of different prosthodontic alloys. Int Dent J 1999;49:361-367.

9. Kedici PS, Memikoğlu MM, Kansu G, Işimer A, Günhan O. Case report: ionisation tendency of a base metal alloy in the oral environment. Eur J Prosthodont Restor Dent 1995;3:231-234.

10. Kuphasuk C, Oshida Y, Andres CJ, Hovijitra ST, Barco MT, Brown DT. Electrochemical corrosion of titanium and titanium-based alloys. J Prosthet Dent 2001;85:195-202.

11. Reclaru L, Lüthy H, Eschler PY, Blatter A, Susz C. Corrosion behavior of cobalt-chromium dental alloys doped with precious metals. Biomaterials 2005;26:4358-4365.

12. Sun EX, Fine S, Nowak WB. Electrochemical behavior of nitinol alloy in Ringer's solution. J Mater Sci Mater Med 2002;13:959964.

13. Huang HH. Effect of chemical composition on the corrosion behavior of Ni-Cr-Mo dental casting alloys. J Biomed Mater Res 2002;5:458-465.

14. Brune D. Mechanisms and kinetics of metal release from dental alloys. Int Endod J 1988;21:135-142.

15. Bumgardner JD, Lucas LC. Surface analysis of nickel-chromium dental alloys. Dent Mater 1993;9:252-259.

16. Huang HH. Corrosion resistance of stressed NiTi and stainless steel orthodontic wires in acid artificial saliva. J Biomed Mater Res A 2003;66:829-839.

17. Goldberg JR, Gilbert JL. The electrochemical and mechanical behavior of passivated and TiN/AlN-coated CoCrMo and Ti6Al4V alloys. Biomaterials 2004;25:851-864.

18. Jacobsen N, Hensten-Pettersen A. Occupational health problems and adverse patient reactions in periodontics. J Clin Periodontol 1989;16:428-433.

19. Bass JK, Fine H, Cisneros GJ. Nickel hypersensitivity in the orthodontic patient. Am J Orthod Dentofacial Orthop 1993;103:280-285.

20. Schiff N, Grosgogeat B, Lissac M, Dalard F. Influence of fluoride content and $\mathrm{pH}$ on the corrosion resistance of titanium and its alloys. Biomaterials 2002;23:1995-2002.

\section{REFERENCE}

1. Okazakia Y, Gotoh E. Comparison of metal release from various 